\title{
FENOMENA MEREBAKNYA NAPZA DAN GAYA HIDUP
}

\author{
Oleh: \\ Sigit Pranawa ${ }^{1}$, Rahesli Humsona ${ }^{2}$
}

\begin{abstract}
Abstrak
Tujuan penelitian untuk mengetahui fenomena meningkatnya peredaran narkotba dan zat adiktif lainnya (Napza) dan gaya hidup pemakai Napza. Teori yang digunakan adalah teori praktik dari Pierre Bourdieu. Penelitian ini dilakukan di Pusat Rehabilitasi Lido, Sukabumi. Penelitian menggunakan metode kualitatif dengan pendekatan fenomenologi, sampel dengan purposive sampling, pengumpulan data dengan observasi dan wawancara. Analisis data dengan model interaktif yang memiliki komponen reduksi data, penyajian data dan penarikan kesimpulan. Validitas data menggunakan triangulasi sumber dan metode. Hasil penelitian menemukan bahwa pemakai Napza di Pusat Rehabilitasi Lido memiliki rentang usia dari belasan tahun hingga tiga puluhan tahun. Pemakai Napza laki-laki lebih banyak dari pada perempuan. Mereka berasal dari berbagai latar belakang sosial dan ekonomi. Habitus, modal dan ranah membentuk praktik berupa sikap dan perilaku pemakai Napza. Gaya hidup hedonis membuat pemakai menjadi adiktif dalam mengonsumsi Napza. Sehingga pemakai yang sedang menjalani rehabilitasi di Lido, memiliki kekhawatiran akan menemui kesulitan untuk lepas dari Napza. Mereka juga menyadari akan sulitnya menghindari godaan dari komunitas pemakai Napza yang dahulu merupakan ranahnya.

Kata Kunci: Napza, habitus, gaya hidup hedonis.
\end{abstract}

\section{Abstract}

The objective of research was to find out the phenomenon of increasing narcotic and other addictive substance circulation and lifestyle of narcotic, psychotropic and substance abusers. The theory used was Pierre Bourdieu's practical theory. This research was conducted in Rehabilitation Center, Lido, Bogor. This research employed a qualitative method with phenomenological approach; sample was taken using purposive sampling; data collection was carried out using observation and interview. Data analysis was carried out using an interactive model of analysis using data reduction, data display and conclusion drawing. Data validation was carried out using source and method triangulation. The result of research showed that narcotic, psychotropic and substance abusers in Rehabilitation Center, Lido, were teens to thirty years old. Male narcotic, psychotropic and substance abusers are more than the female ones. They came from various social and economic backgrounds. Habitus of capital and domain created practice in the form of narcotic, psychotropic and substance abusers' behavior and attitude. Hedonistic lifestyle made the abuser addicted to consume narcotics, psychotropic and other substances. Thus the abusers undertaking rehabilitation in Lido

\footnotetext{
${ }^{1}$ Staff Pengajar Program Studi Pendidikan Sosiologi Antropologi-FKIP-UNS

${ }^{2}$ Staff Pengajar Jurusan Sosiologi FISIP Universitas Sebelas Maret
} 
worried that they would find difficulty of escaping from narcotic, psychotropic and substance abuse. They also realized the difficulty of avoiding the narcotic, psychotropic and substance abuser community formerly being their domain.

Keywords: narcotic, psychotropic and other substance, habitus, hedonistic lifestyle

\section{PENDAhuluan}

Narkoba, Psikotropika dan Zat Adiktif lainnya (Napza) merupakan persoalan lintas batas negara paling berbahaya yang dapat merusak kehidupan, bukan hanya satu atau dua orang saja, namun seluruh masyarakat dunia (Winarno, 2014). World Drugs Report tahun 2015 yang diterbitkan oleh UNODC, organisasi dunia yang menangani masalah narkotika dan kriminal, memperkirakan terdapat 246 juta orang atau 5,2 persen dari populasi dunia yang berusia 15-64 tahun, atau dapat pula dikatakan bahwa 1 dari 20 orang berusia 15-64 tahun, pernah menyalahgunakan Napza (BNN, 2015).

Di tingkat global, jumlah penyalah guna meningkat 3 juta. Sementara peredaran narkotika jenis baru (New Psychoactive Substances/NPS) meningkat hingga 643 jenis zat dan belum seluruhnya terjangkau oleh aturan hukum yang berlaku di setiap negara. NPS yang sudah masuk ke Indonesia mencapai 44 jenis zat. Ada 18 jenis zat di antaranya telah diatur dalam Peraturan Menteri Kesehatan RI, sementara 26 jenis zat lainnya masih dalam proses pembahasan aktif antara Badan Narkotika Nasional (BNN) bersama Kementerian Kesehatan RI (Kemenkes RI) dan instansi terkait lainnya. Peredaran Napza lewat internet pun meningkat terutama untuk transaksi Napza baru.

Tingginya jumlah penyalah guna Napza di Indonesia sudah menunjukkan kondisi darurat Napza. Angka prevalensi penyalah guna Napza di Indonesia pada survei tahun 2015 mencapai 2,20 persen atau lebih dari 4 juta orang. Dari jumlah itu, $22 \%$ di anataranya adalah pelajar dan mahasiswa. Hal ini mengkhawatirkan, karena dampak buruk tidak hanya pada orang yang bersangkutan, namun juga lingkungan di sekitarnya, di antaranya adalah tindak kejahatan, orang tua yang menelantarkan anaknya, perilaku seks menyimpang dan dampak buruk yang mengakibatkan kematian.

Masa remaja juga merupakan masa transisi, di mana remaja sering menghadapi permasalahan yang kompleks dan sulit ditanggulangi sendiri. USAID (2015) menyebutkan, tiga risiko yang sering dihadapi oleh remaja (TRIAD KRR) yaitu risiko- 
risiko yang berkaitan dengan seksualitas (kehamilan tidak diinginkan, aborsi dan terinfeksi Penyakit Menular Seksual), penyalahgunaan NAPZA, dan HIV/AIDS. Masa transisi kehidupan remaja dibagi menjadi lima tahapan (Youth Five Life Transitions), yaitu melanjutkan sekolah (continue learning), mencari pekerjaan (start working), memulai kehidupan berkeluarga (form families), menjadi anggota masyarakat (exercice citizenship), dan mempraktekkan hidup sehat (practice healthy life). Remaja yang berhasil mempraktekkan hidup sehat, diyakini akan menjadi penentu keberhasilan pada empat bidang kehidupan lainnya. Dengan kata lain apabila remaja gagal berperilaku sehat, maka kemungkinan besar remaja tersebut juga akan gagal pada empat bidang kehidupan lainnya.

Di tengah keterbatasan fasilitas serta sarana dan prasarana yang dimiliki, BNN berupaya secara maksimal menghadapi ancaman penyalahgunaan Napza yang semakin mengkhawatirkan (Purnamasari, 2015). BNN juga memiliki program pemulihan dari ketergantungan Napza. Pada dasarnya program pemulihan dibuat untuk memenuhi permintaan masyarakat yang menghendaki supaya para pecandu mendapatkan perawatan dan program yang dapat membuat mereka berhenti menggunakan narkoba, dan setelah itu baru mereka dapat kembali berguna bagi masyarakat dengan kapasitas yang mereka miliki (Santoso, 2004: 28). Namun tidak sedikit penyalah guna Napza yang telah melalui program pemulihan bisa relapse (kambuh). Pada tahun 2006, angka relapse pada penyalah guna Napza sekitar 75\%. (BNN, $2008: 31$ ).

Data jumlah teman penyalah guna Napza mengilustrasikan adanya jejaring penyalah guna Napza. Rerata jumlah seluruh teman penyalah guna Napza sebanyak 13 orang. Ada sekitar $20 \%$ dari teman penyalah guna yang meninggal akibat Napza. Adanya jejaring penyalah guna Napza, diduga menjadi salah satu faktor relapse pada pengguna. Melihat pentingnya jejaring, penelitian ini mengkaji tentang fenomena meningkatnya peredaran Napza dan gaya hidup hedonis penyalah guna Napza.

\section{METHODOLOGY}

Penelitian ini menggunakan metode deskriptif kualitatif. Lokasi penelitian di Pusat Rehabilitasi Lido, Bogor. Informan penelitian adalah penyalah guna Napza yang sudah menjalani tahap akhir rehabilitasi serta para petugas di pusat rehabilitasi tersebut. 
Untuk menentukan informan digunakan purposive sampling (Moleong, 1995). Pengumpulan data dengan observasi dan wawancara. Analisis data dengan model interaktif yang memiliki komponen reduksi data, penyajian data dan penarikan kesimpulan (Miles dan Huberman, 1992). Validitas data menggunakan triangulasi sumber dan metode.

\section{HASIL}

\subsection{Pusat Rehabilitasi Lido Bogor}

Balai Besar Rehabilitasi Badan Narkotika Nasional Indonesia (Babesrehab BNN) adalah sebuah tempat yang dikhususkan untuk merehabilitasi korban penyalahgunaan Napza di Indonesia. Rehabilitasi adalah jalan yang baik bagi proses penyembuhan korban penyalahgunaan Napza. Pusat rehabilitasi Napza BNN terletak di Desa Wates Jaya, kecamatan Cigombong, Lido, Kabupaten Bogor. Balai Besar Rehabilitasi BNN diawali dengan Wisma Parmadi Siwi pada 31 Oktober 1974. Pada mulanya Wisma Parmadi Siwi bertujuan untuk mendidik tahanan anak nakal dan Pekerja Seks Komersial (PSK), kemudian pada tahun 1985, wisma ini menjadi tempat rehabilitasi bagi anak nakal dan korban Napza. Pada tahun 2002, namanya berubah menjadi Unit Terapi dan Rehabilitasi (UPT T\&R) BNN Lido, tujuannya menjadi tempat rehabilitasi para penyalah guna Napza. Hingga belakangan ini, namanya berubah menjadi Balai Besar Rehabilitasi Badan Narkotika Nasional, disingkat Babesrehab BNN.

Pelaksanaan pelayanan di Babesrehab BNN bagi pecandu dan penyalah guna Napza menggunakan sistem one stop center terdiri dari pelayanan rehabilitasi medis dan rehabilitasi sosial dalam satu atap. Babesrehab ini memiliki struktur organisasi dan dipimpin oleh Kepala Babesrehab BNN. Pada pelayanan rehabilitasi sosial menggunakan metode Therapeutic Community (TC) dengan kapasitas daya tampung berjumlah 500 orang yang berlangsung selama 6 bulan. Bangunan berada di atas tanah seluas 112.000 $\mathrm{m} 2$ dengan fasilitas seperti olahraga, pusat keterampilan hingga kegiatan sosial.

Penelitian ini menemukan penyalah guna Napza semakin bervariasi menurut latar belakang sosial ekonomi. Penyalah guna Napza di Pusat Rehabilitasi Lido berusia antara 17 sampai 42 tahun. Mereka berasal dari berbagai tingkat pendidikan, ekonomi, profesi, dan wilayah asal. Mereka ada yang baru saja memulai, ada yang sudah akan keluar setelah melalui tahap rehabilitasi. 


\subsection{Habitus Pengguna Narkoba}

Ada beberapa kualifikasi istilah berkaitan dengan narkoba: penyalah guna, pecandu dan kurban. Yang dimaksud dengan kurban penyalahgunaan narkotika, menurut penjelasan Pasal 54 UU No. 35 Tahun 2009, adalah seseorang yang tidak sengaja menggunakan narkotika karena dibujuk, diperdaya, ditipu, dipaksa, dan/atau diancam untuk menggunakan narkotika. Dengan demikian seorang korban penyalahgunaan narkotika harus terbukti tidak mempunyai unsur kesengajaan mempergunakan narkotika secara melawan hukum dikarenakan adanya keadaan (seperti dipaksa atau diancam) yang membuat ia mau tidak mau menggunakan narkotika atau karena ketidaktahuan yang bersangkutan kalau yang digunakannya adalah narkotika (seperti ditipu, dibujuk, atau diperdaya) (Hendro, 2014).

Di samping istilah narkotika, dikenal juga narkoba dan Napza. Mengacu Wikipedia.org, narkoba adalah singkatan dari narkotika dan obat/bahan berbahaya. Selain "narkoba", istilah lain yang diperkenalkan khususnya oleh Kementerian Kesehatan Republik Indonesia adalah Napza yang merupakan singkatan dari narkotika, psikotropika, dan zat adiktif. Semua istilah ini, baik "narkoba" ataupun "napza", mengacu pada kelompok senyawa yang umumnya memiliki risiko kecanduan bagi penggunanya. Menurut pakar kesehatan, narkoba sebenarnya adalah senyawasenyawa psikotropika yang biasa dipakai untuk membius pasien saat hendak dioperasi atau obat-obatan untuk penyakit tertentu. Namun kini persepsi itu disalahartikan akibat pemakaian di luar peruntukan dan dosis yang semestinya. Mencermati beberapa istilah dan pengertian di atas, penelitian ini merujuk pada istilah penyalah guna Napza.

Yang dimaksud habitus penyalah guna Napza adalah pemahaman dan pengetahuan yang diperoleh melalui keluarga, sekolah dan lingkungan sosialnya. Seluruh informan mengatakan bahwa keluarga terutama orang tua memberikan pengetahuan mengenai larangan menggunakan Napza karena akibat buruknya. Orang tua juga menekankan tentang hukuman berat bagi mereka yang kedapatan menyalahgunakan Napza. Orang tua selalu mengingatkan untuk menjauhi Napza. Namun orang tua tidak mengontrol secara ketat teman-teman pergaulan anak, penggunaan uang saku yang 
diberikan kepada anak, dan barang-barang yang dimiliki anak mereka. Sehingga anak yang semakin dewasa bisa mengatur diri untuk mengelabuhi dari pengawasan orang tua.

Sekolah juga menanamkan tentang bahaya penyalahgunaan Napza. Sekolah lebih ketat dalam mengawasi siswa dengan mewajibkan mereka untuk mengikuti tes bebas Napza. Sekolah juga secara teratur melakukan razia barang-barang yang dibawa siswa. Jika kedapatan membawa barang terlarang, maka akan mendapatkan sanksi. Pada sekolah yang memiliki kontrol yang ketat, tidak memungkinkan siswa untuk menyalahgunakan Napza di sekolah. Mereka melakukannya di luar sekolah.

Teman yang berinteraksi dengan mereka di luar sekolah bisa berarti teman sekolah, bisa juga bukan. Keduanya memiliki peran penting. Teman yang sudah merupakan penyalah guna biasanya akan mengajak untuk mencoba Napza sebagai kesenangan karena mendapatkan sensasi kenikmatan. Bagi mereka yang sedang menghadapi masalah, Napza bisa membantu melupakan dan sesaat mengatasi masalah. Ketika betul-betul menghadapi masalah, Napza diharapkan menjadi jalan keluar. Makin banyak masalah, maka semakin dalam terjerumus dalam penyalahgunaan Napza.

Modal sosial yang dimiliki menyangkut jaringan dan kepercayaan. Jaringan untuk mendapatkan Napza diawali dari teman yang pertama kali menawarkan padanya. Sifat adiksi dalam Napza membuat penyalah guna Napza tertarik menggunakan lagi dan lagi. Semakin lama penyalah guna Napza semakin paham tentang siapa, di mana dan berapa harga yang harus dibayar untuk memperoleh Napza. Sementara kepercayaan dari komunitas untuk menutup mulut demi keamanan bersama akan diperoleh secara bertingkat. Seorang penyalah guna baru hanya akan mengenal orang yang menjual Napza kepadanya. Semakin lama interaksinya akan semakin banyak dan intensif. Kepercayaan ini harus terus dijaga, karena sekali berbuat kesalahan yang dianggap membahayakan maka tidak akan dipercaya. Alasan inilah yang menurut informan bisa memutuskan hubungan dengan komunitas.

Modal budaya menyangkut nilai yang dipahami. Nilai-nilai dari orang tua, sekolah, lembaga agama, lembaga sosial, maupun pemerintah terus menerus mempromosikan hidup sehat tanpa Napza. Bahkan mereka juga memahami bahwa, dalam agama Napza termasuk salah satu barang haram yang harus dihindari. Namun nilai-nilai positif harus berhadapan dengan nilai-nilai negatif yang berasal dari teman mereka. 
Teman yang sudah merupakan pengguna biasanya akan mengenalkan gaya hidup hedonis dengan mengonsumsi Napza untuk kesenangan dan mendapatkan sensasi kenikmatan belaka.Keinginan untuk tetap menjadi bagian dari kelompok, mendorong untuk mencoba mengonsumsi Napza. Sifat adiksi dalam Napza bisa membuat pengguna melupakan nilai yang dimilikinya.

Modal ekonomi menyangkut biaya yang dimiliki untuk mendapatkan Napza. Pada awalnya mereka ditawari Napza secara gratis. Setelah beberapa kali mengonsumsi, mereka harus membayar jika ingin mengonsumsi lagi. Bagi yang berasal dari keluarga kelas menengah ke atas biasanya memiliki uang saku cukup, sehingga bisa digunakan untuk membeli Napza. Faktor uang tidak menjadi masalah. Namun mereka yang berasal dari keluarga kelas bawah, harus berhutang untuk mendapatkan Napza. Selanjutnya untuk membayar hutang, mereka harus menjadi bagian dari pengedar. Ketika sudah masuk dalam jaringan, maka mereka sulit keluar lagi. Inilah yang disebut ranah, yaitu wilayah di mana mereka berada dengan berbagai nilai dan normanya.

\section{DISKUSI}

Dengan menggunakan teori praktik dari Bourdieu, sikap dan perilaku penyalah guna Napza dipahami melalui habitus, modal dan ranah yang melingkupinya. Habitus meliputi pengetahuan, pemikiran dan tindakan. Tindakan rasional merupakan aktivitas manusia yang didasari rasionalitasnya dalam mencapai tujuan tertentu, tetapi rasionalitas tersebut didâsari juga oleh pengetahuan yang didapat dari pendidikan keluarga, sosial dan terlembaga. Habitus merupakan practical sense yang mendorong aktor bertindak dan bereaksi dalam situasi-situasi spesifik dengan suatu cara yang tidak selalu bisa dikalkulasikan sebelumnya, dan bukan sekedar kepatuhan sadar pada aturan-aturan (Prasetyawati dan Ramli, 2012).

Habitus merupakan hasil keterampilan yang menjadi tindakan praktis (tidak harus selalu disadari) yang kemudian diterjemahkan menjadi suatu kemampuan yang kelihatannya alamiah dan berkembang dalam lingkungan sosial tertentu (Bourdieu, 1977:11). Dalam proses perolehan keterampilan itu struktur-struktur yang dibentuk berubah menjadi struktur-struktur yang membentuk. Apa yang dipercaya sebagai kebebasan kreatif sebetulnya merupakan buah pembatasan struktur-struktur. Jadi habitus 
menjadi sumber penggerak tindakan, pemikiran, dan representasi. (Haryatmoko, 2003:10).

Modal ekonomi, budaya, sosial dan simbolik memungkinkan untuk membentuk struktur lingkup sosial. Di antara berbagai macam modal tersebut, modal ekonomi dan modal budaya adalah yang menetukan di dalam memberi kriteria diferensiasi yang paling relevan bagi lingkup masyarakat yang sudah maju. Inilah yang dimaksud dengan struktur modal (Haryatmoko, 2003:11).

Konsep habitus tidak dapat dilepaskan dari konsep ranah perjuangan (champ). Dua konsep itu sangat dasariah karena saling mengandaikan hubungan dua arah: strukturstruktur objektif (struktur-struktur bidang sosial) dan struktur-struktur habitus yang telah terintegrasi pada pelaku (Bourdieu, 1977:9). Konsep ranah perjuangan (champ) menjadi sangat menentukan karena dalam masyarakat yang sangat terdiferensiasi lingkup hubungan-hubungan objektif mempunyai kekhasan yang tidak bisa direduksi pada hubungan yang mengatur bidang lain. Namun pada dasarnya setiap bidang diwarnai oleh postulat Bourdieu (Haryatmoko, 2003:11), yaitu bahwa dalam semua masyarakat ada yang menguasai dan dikuasai.

Habitus meliputi pengetahuan, pemikiran dan tindakan. Tindakan rasional merupakan aktivitas manusia yang didasari rasionalitasnya dalam mencapai tujuan tertentu, tetapi rasionalitas tersebut didasari juga oleh pengetahuan yang didapat dari pendidikan keluarga, sosial dan terlembaga. Habitus merupakan practical sense yang mendorong aktor bertindak dân bereaksi dalam situasi-situasi spesifik dengan suatu cara yang tidak selalu bisa dikalkulasikan sebelumnya, dan bukan sekedar kepatuhan sadar pada aturan-aturan (Prasetyawati dan Ramli, 2012).

Ketika pertama kali menyalah gunakan Napza, tak satupun dari mereka yang telah merencanakannya. Mereka sekedar mengikuti teman yang sudah menyalahgunakan Napza lebih dahulu. Mereka tahu akibatnya, tahu nilai-nilai yang melarangnya, tahu sanksi beratnya. Namun ranah yang melingkupi dan modal sosial berupa jaringan yang bagi mereka sangat berharga membuat mereka abai dengan modal budaya yang selama ini melekat pada mereka. Keinginan tetap diakui sebagai bagian dari kelompok dan daya tarik sensasi kenikmatan membuat mereka akhirnya mencoba menyalah gunakan Napza. 
Sifat adiksi pada Napza membuat mereka terus menerus menyalahgunakan Napza. Gaya hidup hedonis membuat mereka sulit meninggalkan Napza.

Lemahnya kontrol keluarga seperti temuan penelitian ini mengkonfirmasi pendapat Winarno (2014), bahwa maraknya anak-anak muda yang telah menyalahgunakan Napza disebabkan oleh lemahnya kontrol keluarga, maupun aparat terhadap perdagangan Napza di Indonesia. Tanpa kontrol yang ketat mereka semakin terjerumus dalam kubangan Napza. Mereka tetap berperi laku baik dan sopan di dalam keluarga untuk menutupi peri lakunya di luar rumah. Sehingga mereka pada umumnya tertangkap razia ketika berada di luar rumah.

Di antara penyalah guna Napza yang sudah menjalani tahap rehabilitasi dan sudah akan keluar dari Lido, memiliki kekhawatiran akan terpengaruh lagi. Kekhawatiran terbesar adalah menghindari komunitas lama di mana mereka terlibat penyalahgunaan Napza. Mereka mengharapkan dukungan yang besar terutama dari keluarga agar bisa membebaskan diri dari pengaruh komunitas lama.

\section{PENUTUP}

Hasil penelitian menemukan bahwa semua informan setuju bahwa mengonsumsi Napza adalah dilarang. Mereka mendapatkan nilai ini dari keluarga dan sekolah. Keluarga selalu berusaha menanamkan nilai dan norma kebaikan untuk ditaati oleh anggotanya. Keluarga terutama orang tua telah menjelaskan tentang bahaya narkoba bagi kesehatan dân masa depan. Di samping keluarga, membership group juga berpengaruh. Sehingga di samping dari keluarga dan sekolah, pengetahuan selanjutnya didapat dari lingkungan sosial seperti teman bermain di dalam maupun di luar sekolah, teman kerja dan masyarakat di sekitarnya. Interaksi dengan lingkungan sosial ini sangat penting, bahkan dianggap lebih penting dari keluarga.

Jadi habitus penyalah guna Napza umumnya diperoleh dari membership groupnya. Ranah di mana mereka berada akan mewarnai pilihan yang diambil. Sebab ketika beranjak remaja, selain keluarga membership group juga berpengaruh. Bagi penyalah guna ketika masih remaja, interaksi dengan lingkungan sosial ini sangat penting, bahkan dianggap lebih penting dari keluarga. Apalagi jika keluarga atau sekolah justru menjadi sumber masalah bagi remaja. Maka nilai dan norma yang ditanamkan 
dalam keluarga maupun sekolah, dapat tergantikan oleh nilai kelompok. Sifat adiksi pada Napza membuat mereka sulit meninggalkan Napza. Gaya hidup hedonis mendorong mereka terus menerus menyalahgunakan Napza.

Hasil penelitian ini juga menemukan bahwa penyalah guna yang telah melalui tahapan rehabilitasi dan akan segera keluar dari Lido mengkhawatirkan pengaruh kelompok lama. Oleh karena itu keluarga, masyarakat dan lembaga rehabilitasi harus terus mendampingi dan melakukan kontrol lebih ketat, sehingga tidak ada kesempatan bagi kelompok lama untuk mempengaruhi mereka kembali.

\section{DAFTAR PUSTAKA}

BNN, (2008), Pusat Terapi \& Rehabilitasi Badan Narkotika Nasional Indonesia, Terapi Rehabiltasi Komprehensif Bagi Pecandu Narkoba Dilihat Dari Sisi Psikososial.

, (2015), Laporan Akhir Survei Nasional Perkembangan Penyalahguna Narkoba Tahun 2014.

, (2015), Panti Rehabilitasi Narkoba Lido Bogor, https://jauhinarkoba.com/pantirehabilitasi-narkoba-lido-bogor/

Bourdieu, Pierre, (1977), Outline of a Theory of Practice. London: Cambridge, University Press.

Haryatmoko, (2003), Menyingkap Kepalsuan Budaya Penguasa: Landasan Teoritis Gerakan Sosial Menurut Bourdieu. Edisi Khusus Pierre Bourdieu, Majalah Basis, No 11-12 Th ke-52 November-Desember.

Hendro, Nugroho Prasetyo, (2014), Kualifikasi Penyalahguna, Pecandu dan Korban Penyalahgunaan Narkotika dalam Implementasi UU No. 35 Tahun 2009 tentang Narkotika.http://www.kompasiana.com/ hakamain.com/kualifikasi-penyalah guna- pecandu- dan- korbanp-enyalahgunaan-narkotika-dalam-implementasiuu-no-35-tahun-2009-tentang narkotika_54f6eblaa333114e708b462f.

Humas BNN, (2016). Panti Rehabilitasi Narkoba Lido Borgor. https://jauhinarkoba.com/ panti- rehabilitasi-narkoba-lido-bogor/

Lestari, Martina Rosa Dwi, (2016), BNN: 22 Persen Pengguna Narkoba adalah Pejalar dan Mahasiswa, NetralNews.com.http://www.netralnews.com/news/ pendidik an/read/26672/bnn.22.persen.pengguna.narkoba.adalah.pejalar.dan.mahasiswa

Miles, Matthew B., A Michael Huberman, (1992), Analisis Data Kualitatif, UI Press, Jakarta. 
Moleong. Lexy J, (1995), Metode Penelitian Kualitatif, Remaja Rosdakarya, Bandung.

Prasetyawati, YR., G Ramli, (2012), Film Bergenre Horor: Transmisi Nilai-nilai Mistik pada Remaja, Exposure Journal of Advanced Communication, Vol 2 No, 1.

Purnamasari, Deti Mega, (2016), Indonesia Darurat Narkoba. http://www.beritasatu.com/ nasional/371879-kepala-bnn-indonesia-darurat-narkoba.html.

Santosa, (2004), Balai Besar Rehabilitasi Lido, BNN, Jakarta.

Winarno, (2014), Dinamika Isu-isu Global Kontemporer, CAPS, Yogyakarta.

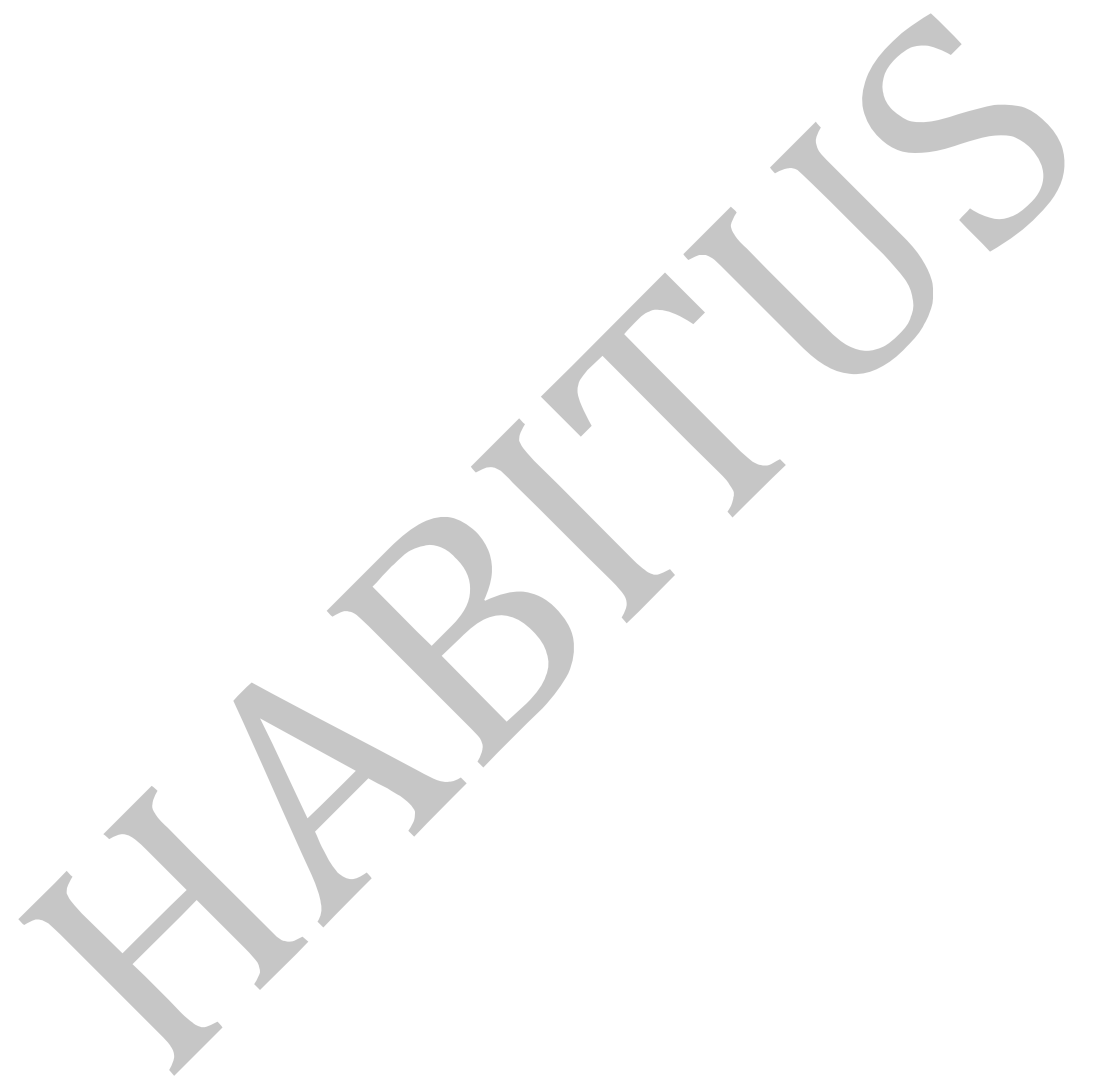

